\title{
Electricity used as additional medium for household supplementary space heating
}

\author{
Jerzy Andruszkiewicz ${ }^{1}$, Józef Lorenc ${ }^{1}$ and Agnieszka Maćkowiak ${ }^{1, *}$ \\ ${ }^{1}$ Poznan University of Technology, Institute of Electrical Power Engineering, Poznań, Poland
}

\begin{abstract}
This article analyses the potential of using electricity for supplementary heating purposes in households during low outside temperatures periods. Space heating using solid state fossil fuels, causes significant pollution of the local environment. In order to assess the potential of replacing fossil fuels with electricity for the supplementary heating purposes, the conditions determining financially reasonable exchanges of the main energy carrier consumption for heating purposes into electricity were analysed as a result of a change in price of this substitute. The concept of cross price elasticity of demand was used to reflect the current price conditions for energy carriers exchange and its values were determined for the energy contained in the most frequently used carriers for heating purposes, in relation to changes in electricity prices. The possible reduction in average electricity prices was considered, resulting from tariff change from a single zone to a two-zone tariff in the case of storage heater use, consuming electricity only in the off-peak zone. What is more, the potential of anti-smog tariff implemented in 2018 concerning the considered aspect was also analysed.
\end{abstract}

\section{Introduction}

Space heating that uses individual residential boilers fuelled with solid state fossil fuels, causes significant pollution of the local environment. The concentrations of harmful particles PM2.5 and PM10 exceed the permissible standards in Poland, especially during the days with low outside temperatures and low windiness, which are characteristic of frosty highs. Under such conditions, any reduction of emissions, which may result from increasing the use of electricity for heating purposes, is extremely important.

Analyses of the growth of consumers' electricity consumption resulting from price demand side response programmes show only a slight increase in the use of electricity for the heating purposes when changing the settlement from the G11 single-zone tariff to the two-zone G12 tariff. The statistics published by the Central Statistical Office and energy suppliers indicate that the number of users of two-zone tariffs exceeds the number of households using electricity for heating purposes. It can therefore be concluded that a large part of two-zone tariff consumers use electricity not as the primary energy carrier for space heating purposes, but for supplementary heating of households.

\footnotetext{
* Corresponding author: agnieszka.mackowiak@put.poznan.pl
} 


\section{Energy carriers used for space heating}

Space heating in households generates the highest energy consumption in relation to other purposes of use. The amounts of energy consumed in particular years, broken down into the purposes of use, are presented in Table 1. Over the years, a decreasing trend can be observed in the amount of energy used for heating, but still energy used for space heating represents on average $69 \%$ [1] of total energy consumed in households.

Table 1. Structure of energy use in households, with specified purposes of use [1]

\begin{tabular}{|c|c|c|c|c|}
\hline Purpose of use & \multicolumn{4}{|c|}{ Energy consumption [GWh] } \\
\hline Year & 2002 & 2009 & 2012 & 2015 \\
\hline Total & 211945 & 217806 & 218333 & 223208 \\
\hline Space heating & 151111 & 152889 & 150278 & 146263 \\
\hline Water heating & 31889 & 31278 & 32222 & 36073 \\
\hline Cooking & 15139 & 17889 & 18056 & 19046 \\
\hline Light \& electrical appliances & 13806 & 15750 & 17777 & 21827 \\
\hline
\end{tabular}

Figure 1 shows the amounts of energy consumed in an average household divided into individual energy carriers. The graph shows that over $80 \%$ of energy consumed in households is supplied in the form of hard coal or firewood, which are the most harmful for humans and the environment, because they generate the highest amounts of suspended PM2.5 and PM10 particles. One of the ways to reduce the problem of low emission is to increase the use of electricity for heating purposes.

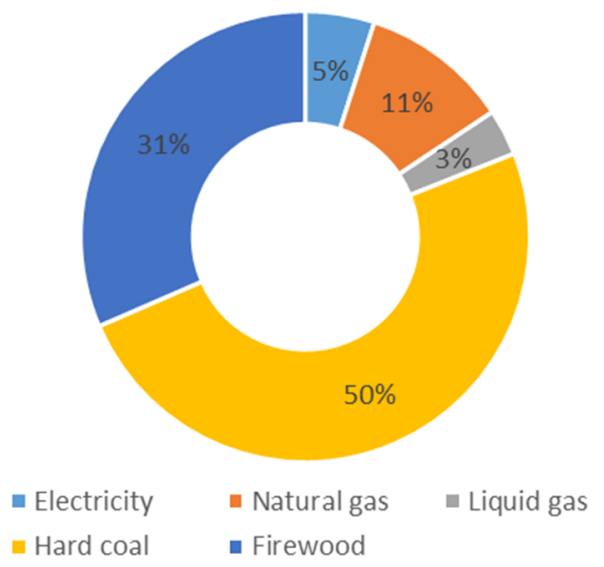

Fig. 1. Average annual energy carriers' consumption in households [1]

The use of electricity for the purpose of supplementary space heating can therefore be considered in two ways: as a displacement of previously used carriers and as an ability to quickly increase thermal comfort due to electricity use. Exchanges in energy consumption for space heating purposes within the basic carrier and electricity, with price changes of these energy carriers, can be determined using the notion of price elasticity of demand. Energy consumption change within two considered carriers may be influenced by two phenomena. First of all, the change in the price of the basic carrier may cause an inversely proportional change in the consumption of this carrier. The consumer's reaction expressed as a change in the consumption of energy carrier $\Delta E$ in relation to its initial consumption $E$ due to the price 
change $\Delta P_{f}$ compared to the initial price $P_{f}$ is called the self elasticity of demand and may be determined with the following equation:

$$
\varepsilon_{s}=\frac{\Delta E}{E} / \frac{\Delta P_{f}}{P_{f}}
$$

The value of price self elasticity of demand, taking into account economic factors, should be negative. The value of self elasticity allows predicting the consumer's reactions to the price change. The second mechanism inducing consumption changes of the basic carrier is the change in the price of the substitute for this carrier, which is electricity. The customer's reactions expressed as the change of the consumption of the basic energy carrier $\Delta E$ in relation to the initial consumption $E$ due to the change in the electricity price $\Delta P_{e}$ in relation to its initial price $P_{e}$ is called cross elasticity of demand and is determined with the following equation:

$$
\varepsilon_{c}=\frac{\Delta E}{E} / \frac{\Delta P_{e}}{P_{e}}
$$

The value of cross price elasticity of demand, taking into account economic factors, should be positive - decreasing the electricity price, resulting in a negative value of $\Delta P_{e}$, causes a negative $\Delta E$ value, so it limits the consumption of the basic carrier.

The model of changes in the use of the basic energy carrier for space heating when using electricity as a supplementary medium for these purposes, for variable carrier prices, can be described using the following equation:

$$
\Delta E=E_{h}-E_{h 0}=E_{h 0} \cdot \varepsilon_{s} \frac{\Delta P_{f}}{P_{f}}+E_{h 0} \cdot \varepsilon_{c} \frac{\Delta P_{e}}{P_{e}}
$$

where: $E_{h}$ - energy used for space heating purposes, $E_{h 0}$ - energy used for space heating purposes before the price changes, $\varepsilon_{s}$ - self elasticity of demand of the basic carrier, $\varepsilon_{c}-$ cross elasticity of demand of the basic energy carrier due to electricity price change, $P_{f}$ - initial unit price of the basic energy carrier, $P_{e}$ - initial unit price of electricity, $\Delta P_{f}$ - change in price of the basic energy carrier, $\Delta P_{e}$ - change in price of electricity.

The first component on the right side of the equation (3) illustrates the change in consumption of the basic energy carrier used for heating purposes, as a result of changes in the price of this medium, while the second component illustrates the reduction of use of the basic carrier due to the reduction in electricity prices. Based on the above model, the decision making process of the owner of a heating installation, regarding energy carriers used for space heating, will be analysed.

To present the chances of increasing the share of electricity in supplementary space heating in Poland, the level of certain energy carriers' prices in Poland should be assumed. These prices per $1 \mathrm{kWh}$ of energy are presented in Table 2 [1-4]. In the following analysis only low-cost supplementary space heating will be considered that does not require the construction of additional heating systems, which is the case for using e.g. heat pumps. The prices of electricity together with its delivery depend on the amount of energy consumed, because distribution network operators' tariffs contain fixed charges, which influence decreases with the increase of the electricity consumption. The unit prices presented in Table 2 have been determined for the example of tariff electricity prices and distribution rates offered to households by the Enea S.A. supplier and the Enea Operator distribution network operator and they concern the case of flat G11 tariff consumer with the output electricity consumption of $4 \mathrm{MWh} / \mathrm{a}$, changing the settlement to the time-of-use (TOU) G12 tariff and, consequently, increasing its annual consumption to $4.379 \mathrm{MWh} / \mathrm{a}$ [5]. For the price level offered in the anti-smog G12as tariff, the consumer consumption would increase to 4.547 $\mathrm{MWh} / \mathrm{a}[5]$. 
Table 2. Unit space heating costs for various energy carriers

\begin{tabular}{|c|c|c|c|c|}
\hline \multirow{2}{*}{ Energy carrier } & \multicolumn{2}{|c|}{ Unit price of the carrier } & Efficiency & $\begin{array}{c}\text { Cost of } \\
\text { heat }\end{array}$ \\
\cline { 2 - 5 } & {$[\mathrm{PLN} / \mathrm{GJ}]$} & {$[\mathrm{PLN} / \mathrm{kWh}]$} & {$[-]$} & {$[\mathrm{PLN} / \mathrm{kWh}]$} \\
\hline District heat & 52.3 & 0.188 & 0.95 & 0.1982 \\
\hline Natural gas & 69.4 & 0.250 & 0.92 & 0.2716 \\
\hline LPG for household purposes & 85.2 & 0.307 & 0.88 & 0.3485 \\
\hline Heating oil & 88.4 & 0.318 & 0.88 & 0.3616 \\
\hline Hard coal & 28.2 & 0.102 & 0.69 & 0.1471 \\
\hline Lignite & 32.7 & 0.118 & 0.69 & 0.1706 \\
\hline Fuel wood & 16.6 & 0.060 & 0.76 & 0.0786 \\
\hline Electricity - G11 flat tariff & - & 0.4548 & 0.99 & 0.4594 \\
\hline Electricity - TOU G12 tariff average* & - & 0.4265 & 0.99 & 0.4308 \\
\hline Electricity - TOU G12 tariff off-peak* & - & 0.2559 & 0.99 & 0.2585 \\
\hline $\begin{array}{c}\text { Electricity - TOU G12as tariff off- } \\
\text { peak* }\end{array}$ & - & 0.2162 & 0.99 & 0.2184 \\
\hline
\end{tabular}

*based on Enea Operator and Enea S.A. tariffs for 2018 [3, 4]

\section{Influence of electricity tariffs on households' load curve}

Encouraging consumers to use electricity for heating purposes is accomplished through electricity tariffs in Poland, mainly by the time-of-use G12 tariff, which distinguishes higher energy and distribution prices during peak periods and lower prices during off-peak periods. This tariff includes an off-peak period during the night hours and during two-hour period in the afternoon (e.g. 1-3 pm). The afternoon off-peak period generates temporarily higher energy consumption, which may pose a threat to the generation adequacy in the power system during these hours. Despite the availability of such a tariff, in Poland still few customers decide to change their settlement from flat to time-of-use tariff. On the basis of [6], it can be assumed that only $22 \%$ of energy consumed in households, i.e. approximately $6.500 \mathrm{GWh}$ per year, is consumed in G12 TOU tariffs.

Since January 2018, the G12as antismog tariff has been introduced, which aims to promote the use of electricity for heating purposes during the night hours. This tariff distinguishes two types of customers, i.e. customers newly connected to the distribution network (G12asn), who are subject to lower electricity rates and existing customers (G12ase), who are settled according to lower electricity fees only after exceeding the consumption limit equal to their last year's annual energy consumption. Electricity prices variability for the TOU G12 and G12as tariffs and for flat G11 tariff, for particular hours of the day for the considered supply and distribution offers is shown in Figure 2. [3, 4]. The prices shown in the chart include a variable rate for electricity and variable distribution rates for 2018 without taxes.

To forecast changes in electricity consumption of consumers transitioning from singlezone tariff to a time-of-use tariff it is necessary to know the load profiles of household customers. Due to the lack of commonly installed smart meters, it is necessary to use standard load profiles of customers, which are published by regional DSOs for particular tariffs, based on energy consumption measurements within groups of typical customers. The standard load profile is a set of data presenting the average electricity consumption in every hour of a year by a group of final customers, who have similar electricity consumption characteristics and 
are not provided with measurement and settlement devices enabling data registration, located in the area of operation of a certain DSO. Profiles have the form of data sets for particular Gxx tariff, containing the values of relative energy consumption in the $i^{\text {th }}$ hour of the year $H G x x_{i}$ of the representative customer expressed in relation to the annual consumption $E_{a}$.

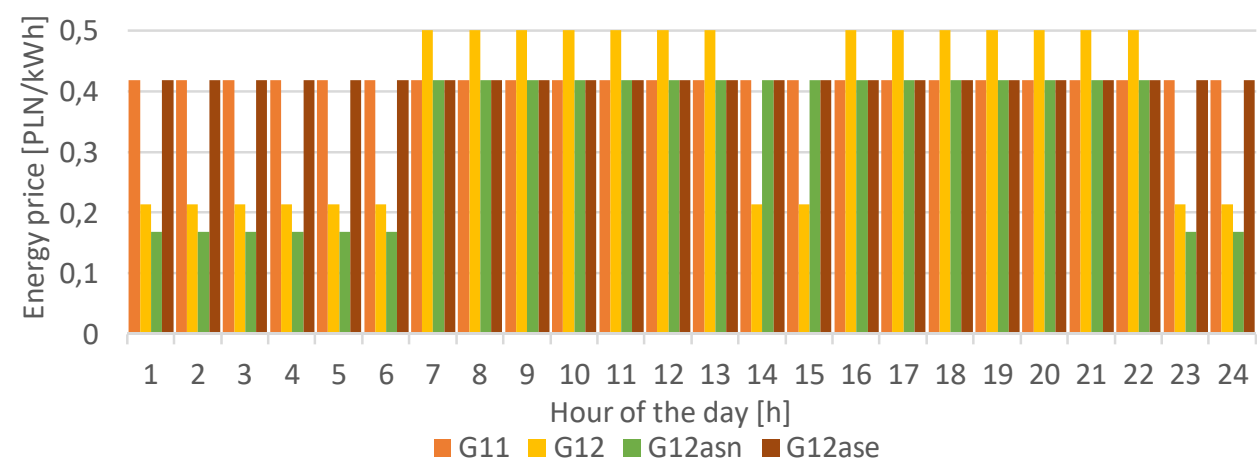

Fig. 2. Variable rates for electricity within the considered tariffs

On the basis of standard load profiles, it is possible to determine the increase in energy consumption for customer transitioning to a TOU tariff. The models of annual consumption increase for G11, G12 and G12as tariffs' customers were determined based on the average elasticity of demand calculated from standard load profiles of those customers published by Enea Operator, as shown in detail in $[5,7]$. In order to analyse in details the customers' behaviour, it is necessary to divide hourly values of energy demand into daily values, specifying peak and off-peak consumption. Such decompositions of customers' load profiles in the G11 and G12 tariffs are shown in Figure 3.

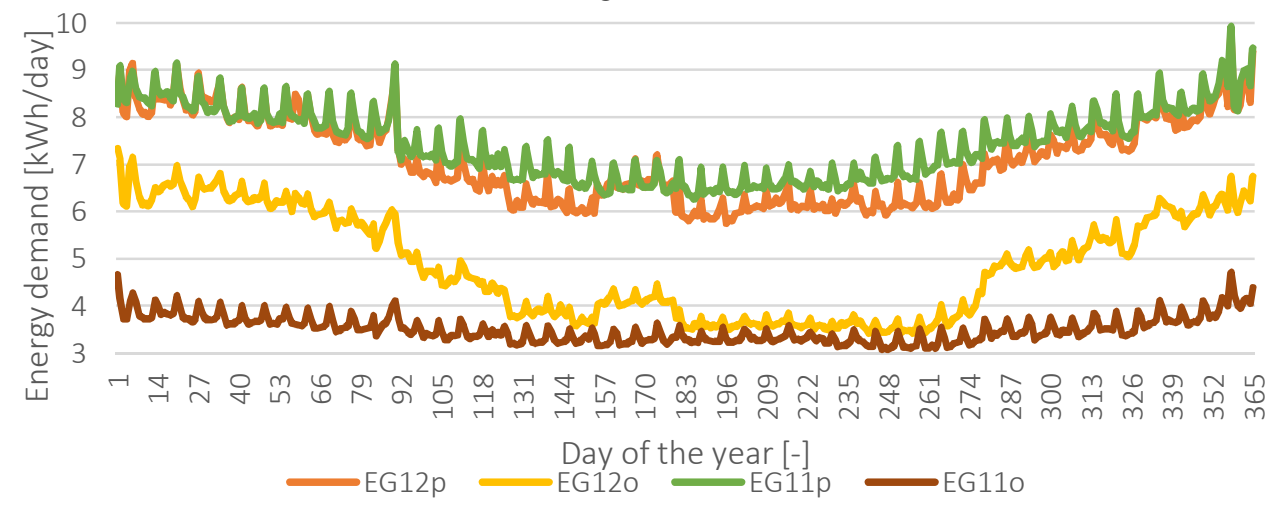

Fig. 3. Energy consumption decomposition into the peak and off-peak periods on individual days of the year 2018 for G11 and G12 tariff customers according to standard load profiles

It is assumed that, outside the heating season, the difference in energy consumption in the peak period of G11 and G12 is equal to the consumption difference between these tariffs in the off-peak period. Therefore, it is possible to determine the increase in energy consumption in the time-of-use tariff compared to a flat one, which results mainly from the higher energy use in the off-peak zone during the heating season, which is the effect of using electricity for space heating purposes. On the basis of standard load profiles, it is possible to determine relatively higher energy consumption in peak periods outside the heating season for G11 customers, showing the shift of energy consumption by household appliances and increasing energy usage in the peak period in the G12 profile compared to the G11 profile during the 
heating season in periods of short days usually connected with low outside temperatures. The analysis presented in $[5,7]$ has been repeated for one of the DSOs for the years 2016-2018, assuming the average consumption of the flat tariff customer for $4000 \mathrm{kWh}$ [5], and the results are presented in Table 3.

Table 3. Electricity consumption increase calculations in the TOU tariffs

\begin{tabular}{|c|c|c|c|c|c|c|}
\hline Year & \multicolumn{2}{|c|}{$\mathbf{2 0 1 6}$} & \multicolumn{2}{c|}{$\mathbf{2 0 1 7}$} & \multicolumn{2}{c|}{$\mathbf{2 0 1 8}$} \\
\hline Period & Peak & Off-p. & Peak & Off-p. & Peak & Off-p. \\
\hline G11 consumption $E_{a G I 1}[\mathrm{kWh} / \mathrm{a}]$ & \multicolumn{2}{|c|}{4000} & \multicolumn{2}{|c|}{4000} & \multicolumn{2}{c|}{4000} \\
\hline G12 space heating $[\mathrm{kWh} / \mathrm{a}]$ & 129.40 & 375.52 & 130.06 & 396.55 & 48.25 & 331.58 \\
\hline Appliances load shift $[\mathrm{kWh} / \mathrm{a}]$ & -152.54 & 152.54 & -174.23 & 174.23 & -166.96 & 166.96 \\
\hline $\begin{array}{c}\text { G12 consumption } \boldsymbol{E}_{\boldsymbol{a} G 12} \\
{[\mathbf{k W h} / \mathbf{a}]}\end{array}$ & \multicolumn{2}{|c|}{4504.95} & \multicolumn{2}{|c|}{4526.32} & \multicolumn{2}{|c|}{4379.83} \\
\hline
\end{tabular}

The values presented in the table above, calculated based on standard load profiles, show only a slight increase in energy consumption when transitioning from G11 to G12 tariff. It can therefore be assumed that the customers usually use electricity for supplementary space heating, retaining another energy carrier as the basic source of heat for heating purposes. The average increase in electricity consumption for space heating in the off-peak period is 367.88 $\mathrm{kWh}$ per year. Based on the analysis of standard load profiles for G11 and G12 tariff in [5], dynamic values of price elasticity of demand for each day in a year were determined. On the basis of the values of self and cross elasticity, the forecasted energy consumption in the antismog G12as tariff for 2018 was determined. It is expected that the annual energy consumption will increase to $4.547 \mathrm{MWh}$ for a customer switching to the G12as tariff from the G11 tariff with an annual consumption of $4 \mathrm{MWh}$.

\section{Electricity use potential for space heating purposes in Poland}

It is possible to use electricity for space heating purposes in two ways: as a carrier partially replacing currently used energy carriers or as a way to quickly improve thermal comfort in households. These methods will be analysed using the model of changes in the use of energy carrier, presented as equation (3). Firstly, the profitability of replacing the previously used carrier by electricity will be considered. It can be assumed that the unit energy price of the primarily used energy carrier for heating purposes does not change and the price of electricity available for heating purposes decreases, so:

$$
\Delta P_{f}=0
$$

$$
\Delta P_{e} \leq 0
$$

then, the equation (3) may be reduced to a following relationship:

$$
\Delta E=E_{h 0} \cdot \varepsilon_{c} \frac{\Delta P_{e}}{P_{e}}
$$

Equation (6) presents quantitatively the exchange relationship of the basic carrier use into the use of electricity instead. But the real exchange in the use of the considered energy carriers should be based on economic reasons, so that it would be profitable for the customer. Therefore, the additional condition must be met, taking into account the appropriate carriers' price relationship and the necessity to purchase additional equipment, for the $C_{\text {eqe }}$ cost, converting electricity into heat, which can be presented as follows:

$$
C_{e q e}+\Delta E \cdot\left(P_{e}-\Delta P_{e}\right)<\Delta E \cdot P_{f}
$$


After transforming the above equation, the following may be formulated:

$$
\frac{C_{e q e}}{\Delta E}<P_{f}-\left(P_{e}-\Delta P_{e}\right)
$$

Analysis of the equation (8) may lead to the following conclusions:

- to substitute the previously used energy carrier with electricity, the electricity price must be lower than the price of the substituted carrier,

- price difference between the previously used carrier and electricity (after electricity price reduction), should be higher than the equipment cost used for space heating per unit of consumed electricity,

- with small positive differences in the prices of the energy carrier used so far and electricity, the cost-effectiveness of using electricity depends on the amount of energy used $\Delta E$ and therefore indirectly increases with the period duration for which the profitability is determined.

Decreasing the price of electricity is possible when there is a reduction in electricity prices or when the household customer decides to change electricity settlement for a tariff that allows its use at lower prices. Thus, for the example shown in [5], a customer changing the settlement to the G12 tariff and using energy in the night valley and during peak hours only on the coldest days, the price for electricity falls to the value given in Table 2 as G12 average. When the customer uses heating only in the night-time valley, because of storage heater use, the electricity price falls to the G12 price for the night valley given in Table 2. For a new customer using the G12as tariff and the storage heater as well, the electricity price falls to the G12as off-peak price shown in Table 2.

The positive value of the right part of the formula (8) presents the condition for replacing part of the energy obtained from the basic carrier with electricity. Otherwise, the customer would have to get a subsidy for the equipment converting electricity into heat (negative $C_{\text {eqe }}$ value). To enable a partial substitution of other carriers generating pollution such as coal or firewood, a reduction in electricity prices along with its distribution fees would be required for heating purposes to the level of $0.14 \mathrm{PLN} / \mathrm{kWh}$. For current prices of energy carriers, such substitution is possible only for heating oil in the case of using electric storage heaters (inducing energy consumption during the night valley). The profitability of the substitution of the basic carrier by electricity in this case is illustrated in Figure 4, where the unit cost and the total cost of substitution for two variants were analysed:

- use of the anti-smog G12as tariff during the night valley $\left(P_{f}-P_{e}=0,1432\right)$ and the storage heater with the power output of $1.7 \mathrm{~kW}$ and the price equal to $1200 \mathrm{PLN}$,

- use of the cheapest convector heater at the price of 230 PLN with a capacity of $2.3 \mathrm{~kW}$ with the energy use settlement according to G11 flat tariff, i.e. for the possibility of using heat from this source at any time at a fixed price of electricity.

Electricity consumption[kWh]

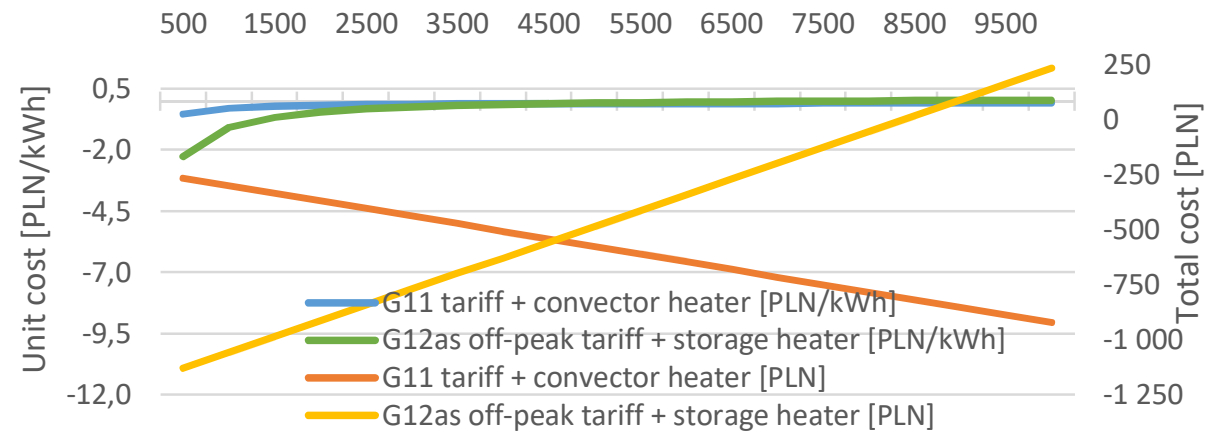

Fig. 4. Unit and total cost of substituting the heating oil with electricity for heating purposes 
Due to Figure 4, the substitution costs with the use of a storage heater are negative, but the loss decreases with the increase of energy consumed, which may lead to the profitability of space heating with electricity with a longer period of analysis. In the case of the G11 tariff and convector heater, the costs are monotonically increasing along with the energy consumption, but for a low consumption level they are lower than the costs in the case of a storage heater and perhaps the most economical way to increase the heat comfort instantly.

The quick and not expensive increasing of thermal comfort in households is the other way of making use of electricity for space heating purposes. Thermal comfort can be improved by increasing the use of the basic energy carrier or electricity. Supposing that, for increasing thermal comfort with the use of any energy carrier, it is necessary to use additional equipment, therefore, in addition to the previously described cost of electrical equipment $C_{\text {eqe }}$, it is necessary to take into account the cost of additional equipment for the basic heat carrier $C_{\text {eqf }}$. This cost includes modernization of the heating installation for the basic carrier and providing the rooms with additional heaters. The equation determining the profitability of electricity use for heating purposes, under the applicable conditions (4) and (5), will then have the following form:

$$
C_{\text {eqe }}+\Delta E \cdot\left(P_{e}-\Delta P_{e}\right)<\Delta E \cdot P_{f}+C_{\text {eqf }}
$$

which, after the transformations, formulates into the following inequality:

$$
\frac{C_{e q e}-C_{e q f}}{\Delta E}<P_{f}-\left(P_{e}-\Delta P_{e}\right)
$$

Inequality (9) means that the costs of using electricity and equipment per unit of electricity used, should be lower than the costs of using the basic energy carrier for heating, enlarged by the costs of upgrading the primary heating system. The equipment enabling the use of electricity is portable, and its use, in majority of cases does not require modernization of the power installations in the premises. Every day used electric devices, such as electric cookers or electric kettles, have unit powers comparable or exceeding those required for electric heaters used for heating purposes.

It is worth to present the conducted considerations in the realities of Polish households on the basis of previous experience resulting from the use of electricity for heating purposes, which is the effect of a tariff change from G11 to G12 for a household customer. Such a change usually causes an increase in energy consumption $\Delta E$ of $200-500 \mathrm{kWh}$ per year depending on the annual energy consumption in G11 tariff, i.e. on the size of the household. For such a value $\Delta E$, based on the equation (11), the practical value of the investment difference for the heating installations, necessary to obtain the profitability of using electricity to improve the thermal comfort in households, may be formulated as:

$$
C_{e q f}-C_{e q e}>\Delta E \cdot\left(\left(P_{e}-\Delta P_{e}\right)-P_{f}\right)
$$

In the case of coal and even $\Delta P_{e}=0$, i.e. using G11 tariff for the above-mentioned range of $\Delta E$, the difference in costs of modernization of the installation is up to $150 \mathrm{PLN}$, so then the use of electricity becomes very real also due to the possibility of using portable electric heaters immediately. The use of the G12 tariff allows to reduce the price of electricity when using the radiator heater only 2 hours during afternoon and during the night.

Areas of profitability of electricity use in the G12 tariff by using portable electric heaters to improve thermal comfort, in the case of using coal as a basic carrier for space heating is depicted in Figure 5, based on equations (9) and (10). The yellow curve represents the difference in energy prices for the carriers. Blue curves represent differences in equipment costs converted into a unit of electricity used to improve thermal comfort. The use of electricity is more cost-effective than the basic carrier for small $\Delta E$ values, from the beginning of the horizontal axis to the intersection point with the yellow straight line. Increasing the thermal comfort is always connected with expenses and the costs grow with an increase of $\Delta E$ in line with a red curve, with unit costs $\left(\Delta E / C_{e q e}\right)$ depicted in a dark red. 


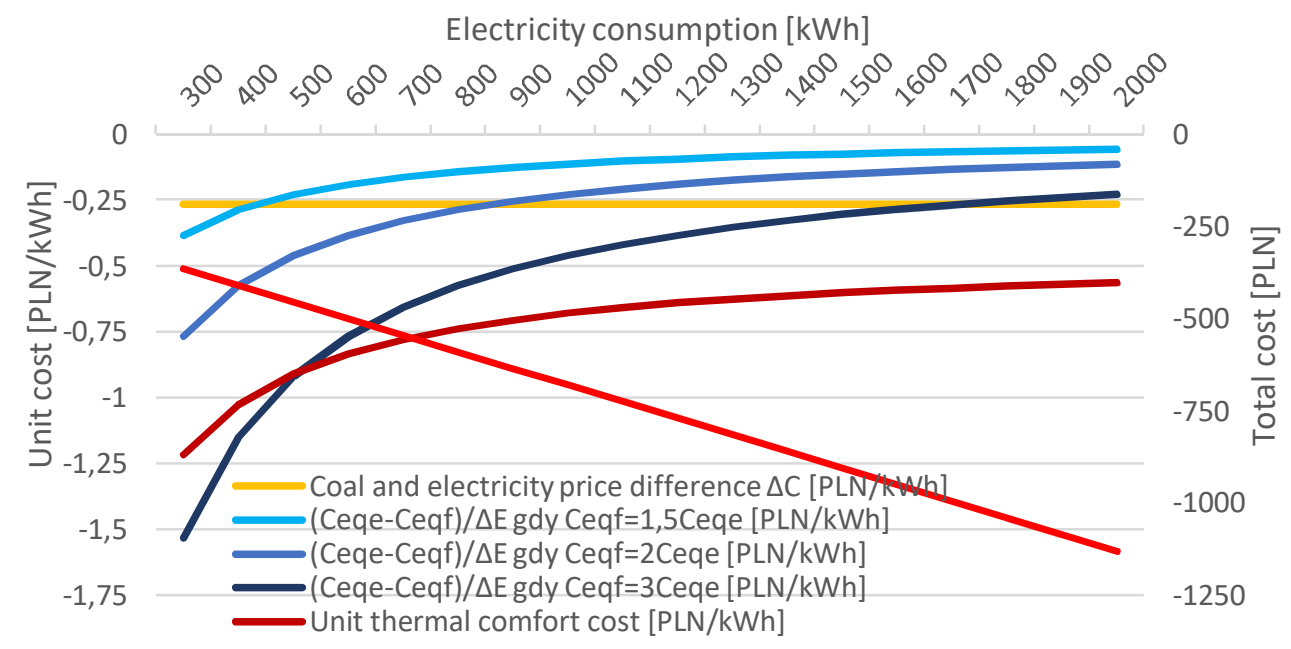

Fig. 5. Profitability of replacing coal with electricity for improving the thermal comfort

The conducted analysis shows that it is possible to replace environmentally harmful heating energy carriers with electricity for the purpose of improving thermal comfort with limited costs of electric heaters acquired for this goal. It is important to determine to what extent changes in electricity prices affect this phenomenon, which can be done by determining the values of cross elasticity of demand based on the relationship (2) for different prices of electricity, taking into account the possibilities of using the available tariff offers. Such calculations are presented in Table 4, assuming energy consumption $E$ for household heating purposes with an average floor area in Poland equal to $78.2 \mathrm{~m}^{2}$ [1] and annual value of the building's primary energy requirement for heating, ventilation and hot water preparation equal to $95 \mathrm{kWh} / \mathrm{m}^{2} /$ year [8]. The values of cross elasticity were calculated for two variants: assuming energy consumption during the whole day with the average energy price in the G12 tariff and assuming energy consumption only in the off-peak period with off-peak prices for G12 and G12as tariffs. The results of calculations are presented in Table 4. The calculated level of cross elasticity of demand values are quite low and for the G12 tariffs they reach 0.7 . It means, however, that the reduction in the price of electricity in the G12 tariff, i.e. the possibility of reheating by $1 \%$ per day, leads to the replacement of thermal energy from other carriers by $0.7 \%$. Elasticity for electricity prices in the off-peak period is much lower, at the level of $0.11-0.14$, which proves the low use of this kind of possibilities due to the need to increase comfort predominantly during the day and relatively expensive storage electric heaters which would enable such functionality using low electricity price periods.

Table 4. Cross elasticity of demand values for coal and electricity

\begin{tabular}{|c|c|c|c|c|}
\hline Tariff & \multicolumn{3}{|c|}{ G12 } & G12as \\
\hline Year & 2016 & 2017 & 2018 & 2018 \\
\hline Energy consumption change $\Delta E[\mathrm{kWh} / \mathrm{a}]$ & -375.52 & -396.55 & -331.58 & -547 \\
\hline G11 tariff electricity price $P_{e}[\mathrm{PLN} / \mathrm{kWh}]$ & 0.4593 & 0.4588 & 0.4594 & 0.4594 \\
\hline G12 tariff electricity average price $[\mathrm{PLN} / \mathrm{kWh}]$ & 0.4293 & 0.4258 & 0.4308 & - \\
\hline G12/G12as tariff off-peak price $[\mathrm{PLN} / \mathrm{kWh}]$ & 0.2532 & 0.2569 & 0.2585 & 0.2184 \\
\hline Cross elasticity $\boldsymbol{\varepsilon}_{\boldsymbol{c}}$ for $\mathbf{2 4} \mathbf{h}$ & $\mathbf{0 . 7 7 3 9}$ & $\mathbf{0 . 7 4 2 1}$ & $\mathbf{0 . 7 1 6 9}$ & - \\
\hline Cross elasticity for the off-peak period & $\mathbf{0 . 1 1 2 6}$ & $\mathbf{0 . 1 2 1 3}$ & $\mathbf{0 . 1 0 2 1}$ & $\mathbf{0 . 1 4 0 4}$ \\
\hline
\end{tabular}




\section{Summary}

The analysis of the possibilities of using electricity for space heating proves, unfortunately, a low potential of using this medium in the studied area. The complete replacement of the most frequently used fossil fuels and firewood with electricity is not profitable for households, due to the high average price of electricity. Only for the most expensive fossil energy carriers, in the case of very high energy consumption and long operation time of electric storage heaters, the return of the incurred expenses would be possible, due to the trend of decreasing costs shown in Figure 4. Despite the lack of possibility of a complete replacement of other carriers with electricity, there is potential of its use for increasing the thermal comfort of residents. Increasing the thermal comfort is always connected with the necessity of incurring additional costs, however for low amounts electricity used, these costs will be lower in most cases, than in the case of other energy carriers. This conclusion may be confirmed by the average increase in demand for electricity when transitioning from G11 to G12 tariff of up to several hundred kWh per year, which seem to be the amount necessary for supplementary space heating in order to increase thermal comfort.

The phenomenon of increasing thermal comfort becomes important with the increasing well-being of the society and it is therefore important to consolidate the trend of using electricity for this purpose. It is necessary to increase the cross elasticity of demand of electricity compared to fossil fuels by lowering the average prices in TOU tariffs used for space heating and to develop the technology for cheaper electric storage heaters, allowing to use low off-peak energy prices, also with lower thermal capacities suitable for reheating rooms. The obtained values of cross elasticity indicate that the price differences of energy in different carriers limit the deeper conversion of energy use into electricity for heating purposes and its current application results from the high availability of equipment allowing to increase thermal comfort in heated rooms at relatively low costs.

\section{References}

1. Energy Consumption in Households in 2015, Central Statistical Office of Poland, Warsaw (2017)

2. Rozporzadzenie Ministra Infrastruktury i Rozwoju z dnia 27 lutego 2015 r. w sprawie metodologii wyznaczania charakterystyki energetycznej budynku lub części budynku oraz świadectw charakterystyki energetycznej (2015)

3. Taryfa dla energii elektrycznej dla odbiorców z grup taryfowych G Enea S.A. Decyzja Prezesa URE z dnia 14 grudnia 2017 r. (2017)

4. Taryfa dla ustug dystrybucji energii elektrycznej Enea Operator Sp. z o.o. Decyzja Prezesa URE z dnia 14 grudnia 2017 r. (2017)

5. J. Andruszkiewicz, J. Lorenc, A. Maćkowiak, A. Michalski., Household price elasticity of demand as a tool for tariff system design leading to increase of electricity use for space heating purposes, European Energy Market Conference 2018 (to be published)

6. Analiza rentowności grup taryfowych na wysokim, średnim $i$ niskim napięciu $w$ przedsiębiorstwach obrotu oraz przedsiębiorstwach zajmujacych się dystrybucja energii elektrycznej w 2017 roku, Agencja Rynku Energii S.A. (2018)

7. Andruszkiewicz J., Lorenc J., Maćkowiak A., Wykorzystywanie inteligentnego opomiarowania dla oceny i ksztaltowania profili obciązeń odbiorców w gospodarstwach domowych, Rynek energii elektrycznej. Aktualne problemy energetyki, 7-20 (2018)

8. Obwieszczenie Ministra Infrastruktury i Rozwoju z dnia 17 lipca 2015 r. w sprawie ogłoszenia jednolitego tekstu rozporzadzenia Ministra Infrastruktury $w$ sprawie warunków technicznych, jakim powinny odpowiadać budynki i ich usytuowanie (2015) 